\title{
Molluscum Contagiosum Over Tattooed Skin
}

*Gonzalo Blasco-Morente, Maria Jose Naranjo-Díaz, Israel Pérez-López, Antonio Martínez-López, Cristina Garrido-Colmenero

$$
\text { المليساء المعدية على الجلد الموشوم }
$$

جونزالو بلاسكو-مورينتى، ماريا خوسيه نارانج-دياز، إسرائيل بيريز-لوييز، أنطونيو مارتينيز لوبيز، كريستينا غاريدو-كولمينيرو
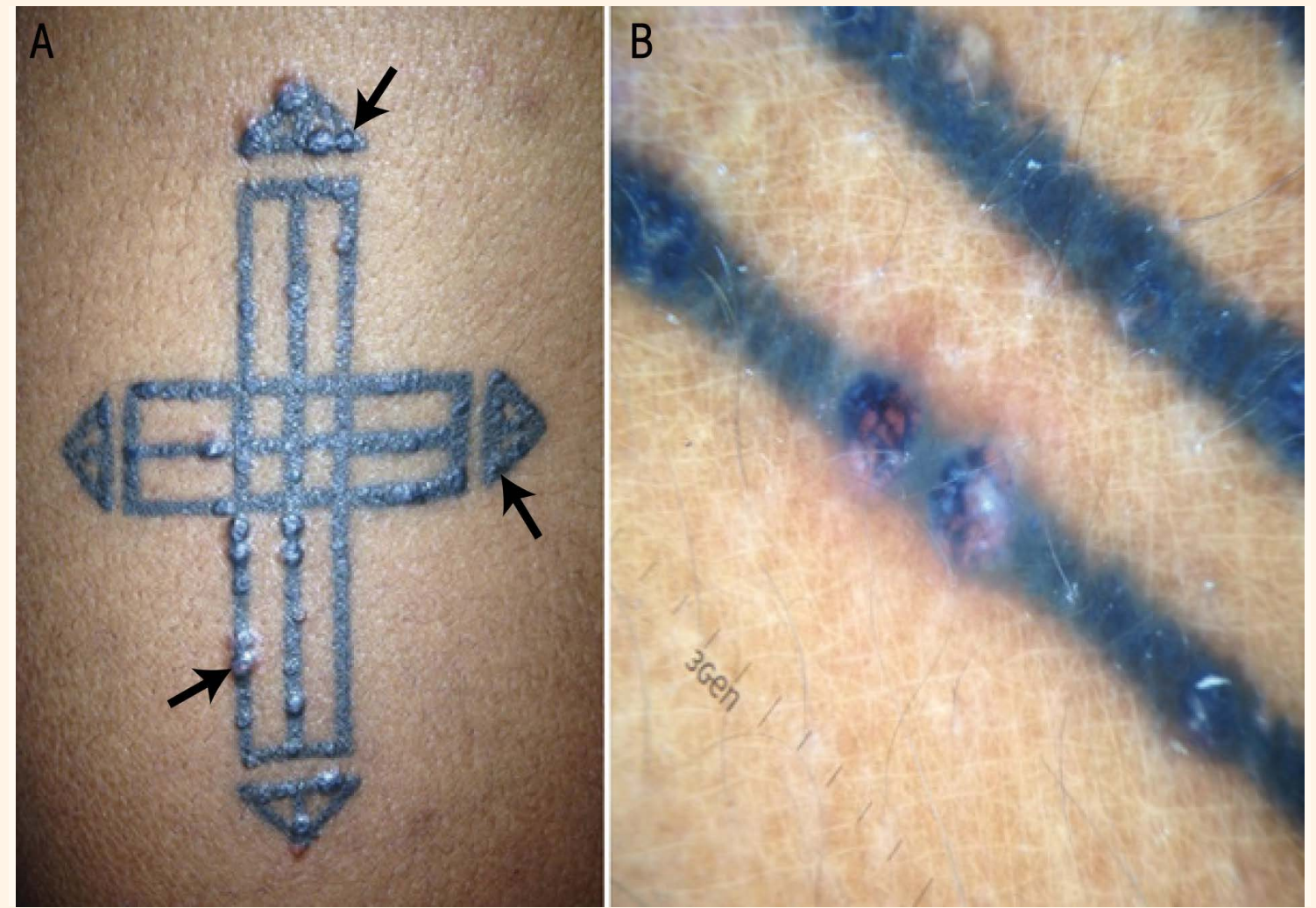

Figure 1A \& B: A: Photograph showing several pearled molluscum contagiosum papules of $0.3-0.5 \mathrm{~cm}$ (arrows) located over a tattoo on the arm of a 33-year-old male patient. B: Dermoscopic image showing the umbilicated papules occurring on the inked lines of the tattoo.

A 33-year-old Spanish male presented to the Department of Dermatology \& Venereology at the Virgen de las Nieves Hospital, Granada, Spain, in February 2015 with pruritic skin lesions located over a tattoo on his right arm. The tattoo had been completed three months earlier without protective measures by the patient's friend at his home. At presentation, the patient was not suffering from any known illnesses. A physical examination showed several pearled papules of
$0.3-0.5 \mathrm{~cm}$ located over the tattoo [Figure $1 \mathrm{~A}$ ]. The papules were umbilicated and occurred over the lines of the tattoo [Figure 1B]. Biochemical tests and a haemogram were normal. Serology for hepatitis B and $C$, human immunodeficiency virus (HIV) and syphilis was negative. The patient was diagnosed with molluscum contagiosum (MC) and treated with curettage, with a subsequent healing time of three weeks. 


\section{Comment}

$\mathrm{MC}$ is an infection caused by a virus of the Poxviridae family; it occurs commonly in children although only occasionally in adults. ${ }^{1,2}$ It presents as small, umbilicated, rose-coloured pearly papules generally located on the trunk and within body folds. ${ }^{2}$ On certain occasions, MC may occur over tattoos in the form of a pseudo-Koebner phenomenon, affecting the ink lines weeks after the tattoo's completion. ${ }^{1-4}$ The Koebner or isomorphic phenomenon occurs when identical clinical and histological lesions develop on traumatised uninvolved areas of skin among patients who already have cutaneous diseases such as psoriasis, vitiligo or lichen planus. ${ }^{2,5}$ When these lesions develop with infections such as $\mathrm{MC}$, it is deemed a pseudo-Koebner phenomenon. ${ }^{2,5}$ In the present case, the patient's tattoo was performed at home by an unqualified tattoo artist; it is very likely that the instruments used were not sterilised which would have increased the risk of secondary infections. The MC virus may have been transmitted via instruments used during the tattooing process or through contaminated ink. ${ }^{2}$ Furthermore, black pigment has been suggested to reduce cellular and humoural immunity. ${ }^{1}$

Syphilis, atypical mycobacteria, hepatitis, HIV, tuberculosis and viral warts may potentially be transmitted during the application of a tattoo. ${ }^{2}$
However, these conditions were not detected in the current patient. The differential diagnosis for $\mathrm{MC}$ includes common warts, condylomata acuminata and granulomatous or inflammatory reactions, such as lichen planus, lichenoid reactions or cutaneous lupus erythematosus-like reactions. ${ }^{1,2,4}$ Deep fungalinfections should also be excluded in immunocompromised patients as they can have a similar presentation. ${ }^{3}$ To confirm a diagnosis of $\mathrm{MC}$, a skin biopsy should be performed. $^{2}$ Treatment options include curettage, cryotherapy, topical keratolytics, topical potassium hydroxide and imiquimod. ${ }^{2,4}$ Otherwise, papules may spontaneously resolve in certain cases. ${ }^{4}$

\section{References}

1. Molina L, Romiti R. Molluscum contagiosum on tattoo. An Bras Dermatol 2011; 86:352-4. doi: 10.1590/S0365-0596201100 0200022.

2. Grillo E, Urech M, Vano-Galvan S, Jaén P. Lesions on tattooed skin: A case study. Aust Fam Physician 2012; 41:308-9.

3. De Giorgi V, Grazzini M, Lotti T. A three-dimensional tattoo: Molluscum contagiosum. CMAJ 2010; 182:E382. doi: 10.1503/ cmaj.091480.

4. Ruiz-Villaverde R, Sánchez-Cano D. Pearled papules over tattoo: Molluscum cotagiosum. Pan Afr Med J 2013; 16:49. doi: 10.11604/pamj.2013.16.49.3442.

5. Thappa DM. The isomorphic phenomenon of Koebner. Indian J Dermatol Venereol Leprol 2004; 70:187-9. 